\title{
The Operation of a Bully Court and Perceptions of its Success
}

\author{
A Case Study \\ J ESSICA MAHDAVI AND PETER K. SMITH \\ Goldsmiths College, London
}

\begin{abstract}
This study investigates one strategy to reduce bullying in schools, the bully court, by way of an intensive case study in one school. Questionnaires and interviews were used in conjunction with the observation of a number of bully courts and access to excerpts from the school's bully court record. The aim was to describe the operation of the bully court and to consi der how successful it was perceived to be by staff and pupils. There was evidence of strong support for the bully court system from both staff and pupils. The limitations of the bully court are also discussed. The school also uses year 12 pupils to act as mentors to year 7 pupils in the context of a wholeschool approach to bullying. This mentoring system and other aspects of the anti-bullying code in place within the school, are discussed with respect to suggested reasons why a bully court is perceived to besuccessful here, when other studies have indicated less positive outcomes.
\end{abstract}

\section{Introduction.}

Over the last decade, various anti-bullying strategies have been developed for use in schools; these include whole-school policy development; curriculum work (videos, drama and role plays, quality circles, literature), playground work (improving the playground environment, training of lunchtimesupervisors), ways of working with pupils whobully (the method of shared concern, the No Blame approach), ways of working

\footnotetext{
Please address correspondance to: J essica Mahdavi or Peter K. Smith, Department of Psychology, Goldsmiths College, New Cross, London, SE 14 6NW, UK. Enquiries to the school involved in this study can beaddressed to: TheH eadmaster, Wath on Dearne Comprehensive School, Sandygate, Wath on Dearne, Rotherham, South Yorkshire, S63 7NW.
}

School Psychology International Copyright (c) 2002 SAGE Publications (London, Thousand Oaks, CA and New Delhi), Vol. 23(3): 327-341. [0143-0343 (200208) 23:3; 327-341; 026235] 


\section{School Psychology International (2002), Vol . 23(3)}

with actual or potential victims (assertiveness training), and ways of involving other pupils in peer support systems (see Naylor and Cowie, 1999; Smith and Sharp, 1994). These methods were outlined in the DFE pack Don't Suffer in Silence(1994), which has now been requested by most state schools in England and Wales and was reissued in 2000.

In an assessment of this pack and of anti-bullying work in schools, Smith and Madsen (1997) found that schools reported using all these methods, and generally found them useful. The only exception was a small number of schools that reported using 'bully courts' (not advocated in the DFE pack) and where level of satisfaction was lower.

Smith et al. (1994) review the origins of bully courts and the limited evidence available on their effectiveness. The idea of school courts or tribunals goes back to the work of educational reformers such as Homer Lane, A.S. Neill, and David Wills in the 1920s to the 1940s. The brief of thesecourts was a very general one; but interestingly, a referencetosuch a court, with specificmention of bullying, is found in E nid Blyton's (1940) novel The Naughtiest Girl in the School:

We hold a big meeting once a week - oftener, if necessary - and we hear complaints and grumbles, and if anyone has been behaving badly we fine them. [The head teachers] come to the meeting too, of course, but they don't decideanything much. They trust us to decidefor ourselves. . . if we haveany complaint at all, wemust bringit totheM eeting and announceit there, sothat everyone may hear it, and decide what is to be done with it. Any bullying, unkindness, untruthfulness, or disobedience may be brought before the Meeting, and we will decide what punishment shall be given. (op. cit., pp 23, 51).

The more recent concept of a bully court, specializing in dealing with cases of bullying, has two sources. Oneis thework of Laslett $(1980,1982)$ who set up a children's court in a day school for maladjusted children. The court was reported to have reduced bullying, and increased awareness of the issue; and those serving on the court gained in self-esteem. However these impressions are not based on systematic data. A second source was the charity Kidscape, which in 1990 issued a one-page sheet of advice and guidance headed 'Bully courts' (al so called 'H onour courts', and later, 'Student councils'). TheKidscapeinitiativein 1990 resulted in a great deal of publicity about theidea of bully courts; it was claimed that 30 schools were using them, and that in eight schools being monitored, reports of being bullied dropped from 70 percent to 6 percent (Elliott, 1991). However, it has been impossible to verify these claims in a publicly accountable way (Smith et al., 1994).

One case study of the development of a bully court was described, by Brier and Ahmad (1991), in a middleschool in Sheffield. A questionnaire evaluation did find a modest fall in bullying in year groups 5 and 6 that 


\section{Mahdavi and Smith: The Operation of a Bully Court}

participated, compared with year groups 4 and 7 that did not. However, the bully court devel opment was supplemented by intensive group work with the head teacher, so it is not clear how much the bully court independently contributed. It was unlikely to be the actual operation of the court, which only met twice in the term!

Pitfield (1992) reported results of a survey of teacher and pupil attitudes to bully courts (being unable to find any schools using it consistently and currently at the time, 1991). She found that teachers wereambivalent. Somethought that bully courts might be punitive, and be perceived to bully bullies. They did feel that it should be part of other strategies (and indeed Elliott, 1991, emphasizes it should be part of a whole school policy approach), and that the preparatory work might be as important as theactual running of the court. Pupils had more positive attitudes than teachers, and many pupils felt that a bully might stop bullying because of being scared of going to the court. It is possible that a bully court could function as a powerful way of mobilizing peer attitudes against bullying; something which is not al ways easy to do, especially in secondary schools (Cowie and Olafsson, 2000; Ol weus and Endresen, 1998).

In any kind of discipline system there is al ways a risk that those in positions of power may abuse that power, instead of using it in the way in which it was intended to be used. There is thus a risk that pupils could misuse the power of the bully court; however, this risk could be reduced or eliminated by ensuring there is al ways a member of staff present who must sanction any decisions of the court. A positive point about bully courts might be the empowerment it gives to pupils. Young people are taught by thebully court system that if something is happeningthat they don't like they can do something about it, learning to help themselves and to hel $p$ each other. It could al so hel $p$ to foster an attitude within the school that 'telling' is acceptable. The bully court representatives in particular aregiven theopportunity togain therespect and trust of their fellow pupils; as Laslett (1980) put it:

'I was frequently amazed at the keen sense of justice these maladjusted children had, and at their acumen. They knew which children were formidable bullies and which children knocked someone about becausethey felt out of sorts. They knew which children invited bullying, and some of these were given a proper ticking off. Their sentences reflected their knowledge of individual children.' (op.cit., p.396)

Bully courts remain something of an enigma in the array of methods available to tackle bullying. In a review, Smith et al. (1994) concluded that 'It is a pity that, as yet, wehaveno good, well-documented studies of a few schools, or even of oneschool, in which this method has been used (and in which thecouncil has met reasonably frequently) over morethan oneor twoterms' (op. cit., p.211). Here, we providesuch a casestudy from 


\section{School Psychology International (2002), Vol . 23(3)}

one secondary school, in which the court had been in existencefor several years; it tried 25 cases during oneschool term which westudied in detail.

\section{The school}

The research was carried out in a large secondary school in South Yorkshire, with approximately 1800 pupils aged 11 to 18 years and over 100 teaching staff. I t is a co-educational state comprehensiveschool that lies within a catchment area comprised of both council and private housing.

Anti-bullying strategies and the devel opment of the bully court

The following account is based on interviews with six members of staff, including the head teacher and those involved in setting up and running the court, together with our own observations and conversations with pupils. Wealso were given permission to sit in on several bully courts as they were held.

Theschool has a number of strategies in place, so that bullying is dealt with from various angles, and in conjunction with other social problems. An 'Anti bullying code' is displayed around the school, and it operates a positivedisciplinesystem, a bully register, a bully court and council, and Year 12 'counsellors' for all the Year 7 pupils (who are in their first year at the school.

The positive discipline system was initiated in 1994/95; as well as being penalized for bad behaviour, pupils are rewarded for positive behaviours. Over time these rewards can build up to give pupils special privileges and treats.

The bully register is a record of every incident of bullying which is reported to or observed by a member of staff. It also contains any incidents that have been dealt with by the bully court.

The bully court started in 1992 as a result of the school addressing its behaviour policies generally. An informal 'behaviour group' was set up by the then deputy head, and in 1992/3 a Year 7 court was run as a trial. The trial was felt to be a success; in 1993/94 the Year 7 bully court ran again and bully courts were introduced into Y ear 8 in 1994/95 and Year 9 in 1995/96; at thetime of study (late 1999) therewerethesethreecourts operating in the school.

Bullies arecalled tothecourt for their appropriateyear group. Theaim of the bully court is to establish whether or not the alleged incident occurred; whether or not it should be classed as bullying; and what punishment (if any) is the most suitable to impose. False accusations of bullying and wasting the court's time may al so be punished by the bully court.

The bully court council aims to increase the pupil participation in the processes dealing with bullying. It consists of the pupil representatives 


\section{Mahdavi and Smith: The Operation of a Bully Court}

from Year 7 to Year 13, plus two senior staff members. After having appeared in the bully court some bullies are called to the council to answer for their behaviour. The idea of the council is to impress upon them the way in which the school as a whole will not accept such behaviour. They havetheopportunity to talk about why they behaved in such a way, and the council has the opportunity to explain why it does not like such behaviour. It is formal, but not confrontational; one of the instructions given toeveryonesitting on the council is that thereisnever to be a raised voice.

The Year 12 mentoring system was introduced in 1996, initially more as a counselling scheme to help pupils who had been bullied and had attended or were to attend the bully court. It was soon decided that only using the Year 12 pupils for the bully court victims was a waste of a valuableresource. Therehad been a lot of discussion about peer mentoring and it was decided to extend thescheme. In September 1999 preparation began for the training of the whole of Y ear 12 to act as mentors for Y ear 7, so that every Year 7 pupil would have a mentor by October half term; however Year 12 pupils could withdraw from the scheme if they wished. Theterm 'counsellors' is still used in the school mainly becausetheY ear 12 pupils preferred it to the term mentor.

This study focuses on the Year 7 court, though the organization for all three courts is similar. Notices about the bully court and its rules are displayed in all Year 7 tutor rooms. At the beginning of the academic year, each of the eleven tutor groups elects two bully court representatives. Theserepresentatives sit on the bully court in teams of six toeight, and three teams operate during different parts of the year under the supervision of a member of staff. This member of staff takes a back seat in the court proceedings, and usually only contributes when needed. The court usually meets once a week (according to demand) and may deal with twoor threecases in onesitting. Thebully court representatives act as a jury in that they discuss the information with which they are presented and make decision as to whether or not theaccused is guilty. However, unlike a jury they also ask questions of all parties involved, and their role includes deciding what punishment to give should one be required.

Incidents of bullying are brought totheattention of the court via notes put into a 'bully box'. There are two bully boxes situated in places that are easily accessible to pupils, without being open to tampering, and theseareemptied daily. Staff often refer pupils whocomplain of bullying to the bully court.

The bully court takes place in a normal classroom, but the desks are moved so that they resemble a courtroom and the procedures are formalized. At the beginning of the session the member of staff in charge discusses any points about which they feel the representatives need to 


\section{School Psychology International (2002), Vol . 23(3)}

be aware. The victim is then brought in, and the letter which they put into the bully box is then read out (often by the victim themselves). The bully court representatives then ask questions of the victim. In most cases, the victim leaves at this point, and the representatives discuss what has been said and decide whether or not they wish to call any witnesses. If witnesses are called, they are brought in one at a time, and questioned individually. Any Y ear 12 mentors may bequestioned, either at this point or at the same time as the pupil with whom they are appearing. The person who has been accused of bullying is then brought in, and they areasked if they know why they have been called tothebully court. If necessary, events are outlined, and again the representatives ask questions. The mentor of the accused can also be involved at this point. The accused leaves, and the case is discussed, with input from the teacher as needed. A verdict is reached, and if necessary a punishment is decided upon. All parties are then informed of the court's decision.

Therearea number of punishments that can beimposed by the court. Theserange from a public warning (given in the bully court), through 5/ 15/30 minutes lunchtime detention, to a 30-minute after school senior staff detention. A letter can be sent to the parents of the bully, or the parents can be requested to visit the school. Depending upon the type of bullying involved, sanctions such as a litter pick, or a ban from using the school bus can be imposed. The bully court can also recommend that the Head Teacher suspends a pupil from school for a period of time.

The bully court representatives decideupon the punishment with help from the presiding teacher. The amount of help given varies with the experience of the representatives involved, so at the beginning the teacher gives more guidancethan is needed after a few weeks. However, all punishments given are sanctioned and supported by the teacher present.

While the punishment aspect of the court is important, it is not the only way in which the bully court might be effective. When a letter is put into one of the bully boxes, the Year 12 mentors of the victim and the accused are notified. The case will be heard at the next bully court, and a notice is read out either in assembly or during the tutor period in the morning. This means that thepeers of thepupils involved know that they have been summoned to the bully court, and as one pupil told us, '. . . everyoneknows you haveto go.' So, all pupils areawarethat beforea case of bullying gets to the bully court everyone will know you haveto go, and your counsellor will expect to discuss the matter with you. These two things prior to the court could be of some deterrent to potential bullies, and may also reduce the number of petty disputes brought to the court.

Theactual attendanceat court is another way in which the bully court has an impact. What actually happens during the court, even though it is not physically intimidating, is not a wholly pleasant experience for 


\section{Mahdavi and Smith: The Operation of a Bully Court}

someone accused of bullying. The bully court representatives quickly gain confidence in their role, and within a few weeks ask questions of their own accord, that is without prompting from theteacher. Duringthe bully courts we observed, we saw very mature behaviour from the bully court representatives, and what happens during the courts seems to be a popular topic of conversation among the friends of theaccused after the court.

If the appearance in court, along with the public nature of the summons to court and the involvement of the Year 12 mentor, is not enough to deter someone from committing an act which would lead to a repeat appearance in the court, then the bully court records may be. The teacher in charge of the bully court keeps a record of all the cases that pass through the court. I includes theletter which was put intothebully box, the names and tutor groups of the pupils involved, a brief summary of the case, and a record of the verdict and any punishment given. This bully court record means that re-offenders are punished more severely, and now works in conjunction with the bully register.

As well as sitting on the court, the bully court representatives can be used to monitor situations. For example, if there has been a problem between two pupils in one particular form, one or both of the bully court representatives in that form can be asked to monitor the situation (with the knowledge of the bully and victim). This means that the court can be made aware quickly if the situation does not improve or deteriorates.

Thereare interactions between the bully court and theother interventions described earlier. Thebully court register includes all cases seen by the bully court, however it can also be used to check if someone who appears to have committed only one offence of bullying has actually committed others and avoided being reported to the bully court. The interactions between the bully court and the Year 12 mentors are numerous and complex. Not all of the Year 12 mentors will have first hand experience of bullying and the bully court, as they deal with all Year 7 pupils. So, experience of the bully court varies between mentors. The mentors can have a huge impact on the bully court in that they add to the processes that are gone through, and can be used to educate the Year 7 pupils. They could potentially prevent bullying from occurring in that they may help to redirect anger or frustration. The relationships they form with the Year 7 pupils may also help to increase the selfconfidence of victims, both to make them less susceptible to bullies, and to increase the likelihood of any instances of bullying being reported promptly.

Having described the development and nature of the bully court, we now report on how it functi oned during theSeptember to December 1999 term; and how it was perceived by pupils and teachers at that time. 


\section{School Psychology International (2002), Vol . 23(3)}

The operation of the bully court over a 3-month period

We were allowed to consult excerpts from the bully court records to obtain details of the sittings, the allegations made, the names of the parties involved, the decision of 'guilty/not guilty' made by the court and the punishment given, if any. Altogether 25 cases of bullying were brought to the Year 7 bully court between September and December 1999, and seen between October 1999 and J anuary 2000. I n one casethe victim did not attend court and the case was not tried.

Theincidents brought beforethecourt included both physical and nonphysical bullying. The non-physical ranged from name-calling and bickering to spreading rumours of a sexual nature and racist namecalling. The physical bullying was mainly pushing, kicking, 'face-pulling' (a term used to describe a particular action to another's face and familiar to the bully court representatives), and taking or damaging possessions (e.g. footballs or school bags). Of the 25 cases, ten were nonphysical, four were physical and 11 were a mixture of both.

The punishments imposed by the court ranged from no real punishment (e.g. where the parties involved were told to stop bickering and try to get on) (two cases) through public warnings (ten cases) to 15 or 30 minute detentions (six cases) and detention plus a letter sent home to the parents/guardians of the bully (six cases, including three in which the accused was the same child). In most cases more serious punishments were given for physical bullying, though the two cases resulting in the most severe punishments (30 minutes detention plus letter home) were for spreading rumours of a sexual nature and racist name-calling.

During the bully courts we attended, the punishment given appeared to be influenced by the attitude of the accused as well as by the nature of theall eged offence. That is, if a pupil began by denying something, and later admitted that it was true, then the earlier lie was taken into account. I f a pupil admitted what they had doneand seemed truly sorry, then they were given the benefit of the doubt and if there was discussion over which of two punishments to give, the less severe one was often chosen. Repeat offenders were punished more severely, and part of the public warning (the least severe punishment meted out by the bully court) states that if a pupil is brought before the bully court on subsequent occasions then the punishment will be more severe.

\section{Bully court attendee interviews}

Altogether 70 interviews were carried out with all the pupils who appeared in the court, as victims ( $n=35)$, those accused of bullying $(n=$ 28), witnesses $(n=4)$ and sixth form counsellors $(n=3)$. Five Year 7 pupils wereinterviewed twice (i.e. for morethan onecase) and twopupils (one victim and one bully) were not interviewed due to absence from 


\section{Mahdavi and Smith: The Operation of a Bully Court}

school. Before each interview the purpose of the study was explained, and each pupil given the option of withdrawing; none did so.

Each pupil was asked whether they thought the punishment decided on by the bully court was fair. Out of 70 responses, 58 thought that the verdict and punishment were fair. One bully was not sure, and three bullies, five victims and one year 12 counsellor thought that the verdict and punishment were unfair (including one bully who felt that the punishment should have been moreharsh). Two bullies had not yet been informed of the verdict/punishment and ther efore could not answer.

The interviews with those pupils who had been bullied showed that the majority (30/35) found the bully court helpful, that it stopped the bullying completely (26) or partially (six) and that they would encourage a friend to use the bully court (30/35). Some reasons given for their support of the bully court included, everyoneknowing that going to bully court sounded more intimidating to bullies and that both sides of the story were put forward.

The interviews with those pupils who had been accused of bullying showed that most (20/28) said that their experience of the bully court would deter them from bullying again; three said it would not and five denied bullying.

We asked victims, bullies, witnesses and also bully court representatives ( $n=14$ ) whether they would use the bully court (again, if a victim), and whether or not the court was perceived to bea better way of dealing with the situation than if a teacher had spoken to the bully and given a punishment. Results are summarized in Table 1. Generally the bully court is seen in a very positive way, though a minority of bullies areless approving.

We asked the victims, bullies and witnesses interviewed $(n=67)$ whether the bully court was the sameas or different from what they had expected; 35 (52 percent) said that their experience of the bully court was different. Reasons given included: the layout of the court, that the representatives asked questions as well as the member of staff, and that telling the truth was taken intoaccount when punishments werechosen. Before their attendance at court, children often expected to appear in a real courtroom; one frequent comment was likethe ones you see on the telly.'

Perceptions of the bully court by pupils and teachers We developed questionnaires for year 7 pupils, year 12 pupils, pupil representatives on the bully court and teaching staff.

\section{Year 7 questionnaire}

A questionnaire was given out to every Year 7 pupil ( $n=301,140$ boys, 161 girls); 164 were returned (77 boys, 84 girls, three no sex recorded), 
School Psychol ogy I nternational (2002), Vol. 23(3)

Table 1 Views of the bully court by pupils who were representatives, or called to the court as victims, bullies or witnesses

\begin{tabular}{lrccccc}
\hline & $\begin{array}{c}\text { If you were bullied, } \\
\text { would you use the bully } \\
\text { court (again)? }\end{array}$ & $\begin{array}{c}\text { Doyou think that the } \\
\text { bully court is more } \\
\text { effectivethan when a } \\
\text { teacher deals with } \\
\text { bullying? }\end{array}$ \\
& Yes & Possibly & No & Yes & Possibly & No \\
\hline Representatives $(n=14)$ & $93 \%$ & - & $7 \%$ & $93 \%$ & - & $7 \%$ \\
Victims $(n=35)$ & $80 \%$ & $11 \%$ & $9 \%$ & $77 \%$ & $17 \%$ & $6 \%$ \\
Bullies $(n=28)$ & $54 \%$ & $21 \%$ & $25 \%$ & $33 \%$ & $58 \%$ & $8 \%$ \\
Witnesses $(n=4)$ & $100 \%$ & - & - & $100 \%$ & - & - \\
\hline
\end{tabular}

a response rate of 54 percent. It looked at awareness of the existence of the bully court, and what they thought the bully court did; whether the pupils were of the opinion that the bully court is good or bad; whether they had been bullied during the autumn term, and, if so, had they used the bully court or the reasons for not doing so;.

Only three of the 164 respondents answered that they were not aware of the bully court in school. From a content analysis of answers to the question 'What doyou think [thebully court] does', 62 werethat thebully court 'stops bullying', 55 mentioned 'punish[ing] bullies', 19 'help[ing] victims' and 13 'help the bully to stop'. Thirteen answers included a comment about 'justice' or 'fairness'. Eight answers did not fit any of these categories and 19 pupils did not reply.

Of the 164 pupils, 140 (85 percent) thought that the bully court was a good thing, 16 a bad thing (eight did not reply).

Forty-six pupils ( 28 percent) said they had been bullied during the present term. Of these, 30 said they had used or would probably usethe bully court; 12 said that they did not intend to do so. Somereasons given for not involving the bully court included: that the bullying had stopped, that it was only a small incident of bullying and the person felt it would be a waste of the court's time, that the bullying happened outside of school, that they werefrightened thebullies would not listen to the court, or the bullying would get worse, that they were embarrassed and that they felt uncomfortable involving the bully court representatives.

No appreciable sex differences were found in any of these replies.

\section{Year 12 questionnaire}

A questionnaire was given to all 117 Year 12 students who had not withdrawn from the mentoring scheme (51 boys, 66 girls). Forty-eight were returned ( 21 boys, 25 girls, two no sex given), a response rate of 41 percent. We asked if they had made or intended to make contact with 


\section{Mahdavi and Smith: The Operation of a Bully Court}

their allocated Year 7 pupils; if they had experienced one of their Year 7 pupils being involved in bullying, and if they had used the bully court.

Thiry-two of the 48 had met with all of their allocated Year 7 pupils, and two had met with some. Of the 14 who had not met with their allocated pupils, only threesaid they did not intend to. Six had been told that one of their pupils had been involved in bullying, and two of these had used the bully court. The four that had not used the bully court mentioned reasons such as: it was a small incident and the bullying had not continued.

\section{Bully court representatives questionnaire}

A questionnaire was given to 66 bully court representatives, 22 from each of Year 7, 8 and 9. Fourteen were returned (ten from Year 7, two from Year 8 and two from Year 9), a response rate of 21 percent (45 percent for Year 7, 9 percent for Years 8 and 9). It asked whether the pupil enjoyed being a bully court representative; 13 said that they enjoyed their role, one gave no answer. The questionnaire also asked whether they would usethebully court if they were bullied, and whether or not they thought the bully court was more effective than a teacher dealing with bullying; results are shown in Table 1.

\section{Staff questionnaire}

A questionnaire was given to all 103 teaching staff (50 males, 53 females). Twenty eight were returned, 13 from males and 15 from females, a response rate of 27 percent. It asked their opinion of the bullying problem in theschool, and whether they werein favour of bully courts, both in general and specifically in their school.

Opinion was split between thinking that the bullying problem in their school was 'slight' (seven) and 'no worse than anywhere else' (20; one 'don't know'). Twenty six out of 28 supported bully courts both in general and in the school where they work (one did not, one 'don't know').

\section{Discussion}

The results show strong support of the bully court from both staff and pupils (both boys and girls). This is true of perceptions of the bully court by Year 7 pupils, year 12 mentors, bully court representatives and teaching staff; though some low response rates to the questionnaires must be borne in mind. This finding is also supported by the nearcomplete record of interviews with those who had been through the 25 bully court cases that term (see Table 1); generally the pupils thought that the court functioned well and was better than a conventional approach by a teacher. Approval was least consistent from thoseaccused of bullying, but even amongst these many approved and most said that it would stop them bullying again. 


\section{School Psychology International (2002), Vol . 23(3)}

A number of factors may hel p explain thelevel of approval of this Year 7 bully court. First, it had existed in the school in some form, for more than seven years. Only those pupils who entered the sixth form from other secondary schools were unfamiliar with it. In fact some of the current Year 12 mentors were among the first bully court representatives in this school. The bully courts are an integral part of the school. Assemblies are planned to explain them to pupils, letters are sent home to inform parents and new staff learn about the bully court system during their induction.

The combination of the bully court system with the bully register proved efficient. Beforethebully court was in placein theschool, it would have been possible (in a year group of 300) for a pupil to be punished for a number of incidents of bullying by a number of the 100 plus members of staff. They could all have been unaware of the other incidents. So a pupil could begiven a series of 15 minutedetentions, when in fact a much more severe punishment was warranted. With the bully court in place re-offenders are dealt with more severely. Thus there is a distinction between someone who commits an act of bullying against a peer, regrets it and learns from his/her mistake, and those which are described by Laslett (1980) as 'formi dable bullies'.

The bully court representatives said that they enjoyed their role. Some reasons given included that they enjoy theresponsibility, that they learn about people, that they enjoy hel ping (both bullies and victims) and that they felt that they could change the ways in which pupils behaved to make Year 7 better. One pupil wrote, 'other pupils came to you if they havea problem'. The representatives could bring their own insights into situations which might arise within the bully court. During one court observed, a representative said '. . . [the accused] is in my form. There's no point in giving him a detention. Teachers give him detention all the timeand henever goes. It won't bother him.' I nstead of giving a detention it was decided to send a letter to the boy's parents, and during the research period there was no recurrence of the bullying.

The Year 12 mentoring scheme is cl osely linked with the bully courts, and cameabout because of their existence. Many of theY ear 12 students said that they found their rolerewarding, and felt that they werehel ping the Year 7 pupils with whom they had been linked. Most felt that the training they had received was adequatefor the rol ethey filled; however it was mentioned that more time could be given over to how bullies should be approached, so that the Year 12 can do more to help bullies as well as victims of bullying.

WhileYear 12 and staff may beableto hel p younger pupils who do not want to be bullies, they may have less success convincing those pupils who are happy to bully others to change. Some pupils we interviewed, who bullied others, did seem tofind bullying acceptable; even if the bully 


\section{Mahdavi and Smith: The Operation of a Bully Court}

court prevented them bullying one victim, they might switch to a different one. This however, is a problem facing all anti-bullying interventions; bully courts and other anti-bullying strategies need other kinds of interventions working al ongsi de them, including working with parents (Smith and Myron-Wilson, 1998).

When we asked about the feelings of parents about their children appearing or being tried in a bully court, we were shown a letter from a parent - theonly letter received about the bully court that academicyear - which thanked the school for having a bully court. In previous years a few parents had written letters, expressing concern about the bully court; these parents had been invited to sit in on a bully court and in every case it was stated that their concern changed to support.

Thestudy did not aimtolook at theeffectiveness of the bully court, but perceptions of its effectiveness. Pitfield's (1992) study showed many of the difficulties involved in finding schools with bully courts to investigate and even schools which were willing to set up courts. It would be useful, however, to carry out a more longitudinal study to examine the effectiveness of bully courts.

Also, the bully court system may vary in effectiveness with age. Our study was of theY ear 7 bully court, but theY ear 8 and 9 bully courts saw fewer cases, and fewer of their representatives replied to our questionnaire. Both the lower response rate from older pupils and the fact that theschool has not extended the courts toyears 10 to 13 interested us. We spoke to the teacher in charge of the setting up and operation of the bully courts about these matters. He explained that it was felt that pupils did not respond as positively to the bully court as they moved further up the school, despite them having experienced it in previous years. Hesuggested that thoseol der pupils whofit intoL aslett's category of 'formi dablebullies' find ways of bullying which the bully court may be less well equipped to deal with. These could be for example more psychological types of bullying; ignoring a pupil rather than taunting him or her, calling him or her names behind his or her back and laughing, rather than saying things to his or her face. Ther eforeit was not intended to extend the use of the courts.

This casestudy suggests that the bully court system can makea useful contribution to combating bullying, in certain circumstances. We hypothesize that these are:

- a well-established and well-publicized system;

- adequatestaff supervision of the court process and training for those pupils involved;

- a well-integrated record system of bullying incidents;

- a combination of thecourt system with a peer mentoring/counselling system which helps/encourages Year 7 pupils to use the bully court. 


\section{School Psychology International (2002), Vol . 23(3)}

In this school, the peer mentoring system used much older pupils (Y ear 12 for Y ear 7), and thesuccess of a bully court system with theol der pupils themselves, remains untested.

Peer support schemes have developed in many UK schools recently, and Cowie (1998) and N aylor and Cowie (1999) discuss theimpact which they can have, either for reducing bullying in schools, or in hel ping pupils to cope with it. Circle time can provide another example of combining direct peer pressureon bullying with a support scheme (HighfieldJ unior School, 1997). In the school we observed, the mentoring system was not in itself intended to combat bullying, but mentors are in a position to learn about an incident of bullying soon after it has happened and then tohel $p$ and encouragetheyounger pupil to report it tothebully court and support them through the process. The support given to a younger pupil by an older pupil and the relationship which forms between them may help to reduce repeat incidents of bullying. The combination of a bully court plus older pupil mentoring/counselling system may thus have much to recommend it.

\section{Acknowledgements}

We would like to thank all of the staff and pupils at Wath on Dearne Comprehensive School who participated in this research, we are especially grateful to Graham Barlow for all the time he spent with us discussing various aspects of the study. We would also like to thank Helen Cowie for her comments on an earlier draft and Sara Kortenray for her help in the preparation of the manuscript.

\section{References}

Blyton, E. (1940) The Naughtiest Girl in the School. London: Hodder and Stoughton.

Brier, J. and Ahmad, Y (1991) 'Developing a School Court as a Means of Addressing Bullying in Schools', in P. K. Smith and D. A. Thompson (eds) Practical Approaches to Bullying (pp.25-36). London: David Fulton

Cowie, H. (1998) 'Perspectives of Teachers and Pupils on the Experience of Peer Support Against Bullying', Educational Research and Evaluati on 4: 108-25.

Cowie, H. and Olafsson, R. (2000) The Role of Peer Support in Hel ping Victims of Bullying', School Psychology I nternational 21: 79-95.

Department for Education (1994) Don't Suffer in Silence London: HMSO. [reissued by Department for Education and Employment, 2000]

Elliott, M. (ed.) (1991) Bullying - A Practical Guide to Coping for Schools. Harlow: Longman.

HighfieldJ unior School (1997). Changing our School: Promoting PositiveBehaviour. Highfield School, Torridge Way, Efford, Plymouth PL 36 QJ , England.

Laslett, R. (1980) 'Bullies: A Children's Court in a Day School for Maladjusted Children', J ournal of Special Education 4: 391-7. 


\section{Mahdavi and Smith: The Operation of a Bully Court}

Laslett, R. (1982) 'A Children's Court for Bullies', Special Education 9: 9-11.

Naylor. P, and Cowie. H, (1999) The E ffectiveness of Peer Support Systems in Challenging School Bullying: The Perspectives and Experiences of Teachers and Pupils', J ournal of Adolescence 22: 467-79.

Olweus, D. and Endresen, I.M. (1998) The Importance of Sex-of-Stimulus Object: Age Trends and Sex Differences in Empathic Responsiveness', Social Development 3: 370-88.

Pitfield, M. (1992) An Investigation into Interest in, and Effectiveness of Bully Courts. Unpublished B.A. dissertation, University of Sheffield.

Smith, P.K., Cowie, H. and Sharp, S. (1994) Working Directly with Pupils Involved in Bullying Situations', in Smith, P. K. and Sharp, S., (eds) School Bullying: Insights and Perspectives (pp.193-212). London: Routledge.

Smith, P.K. and Madsen, M. (1997) A F oll ow-UpSurvey of theDFE Anti-Bullying Pack for Schools: Its Use, and The Development of Anti-Bullying Work in Schools. London: DfEE.

Smith, P. K. and Myron-Wilson, R. (1998) 'Parenting and School Bullying', Clinical Child Psychology and Psychiatry 3: 405-17.

Smith, P. K. and Sharp, S. (eds) (1994) School Bullying: Insights and Perspectives. London: Routledge. 